\title{
The Effect of Cooperative Learning Models and Self Efficacy to Critical Thinking Ability on Social Studies
}

\author{
Roy Barli Sihombing ${ }^{1}$, Etin Solihatin ${ }^{2}$ and Ajat Sudrajat ${ }^{3}$ \\ Elementary Education of Postgraduate \\ State University of Jakarta \\ Indonesia
}

\begin{abstract}
The aim of the study to determine the effect of cooperative learning model and self-efficacy on critical thinking skills in social studies subjects. This research was conducted in the fourth grade of SDN Kedung Badak 2 Tanah Sareal Sub-district, Bogor City. The research design used the experimental method with treatment by level 2x2. Data analysis used 2-way variance analysis (ANOVA). The results of this study are (1) the existence of differences in critical thinking skills using Teams Games Tournament learning model and Student Teams Achievement Divisions. (2) There was an interaction between the cooperative learning model and self-efficacy in students' critical thinking ability. (3) Critical thinking ability of students who have high self-efficacy higher using Teams Games Tournament learning model than using Student Teams Achievement Division learning model. (4) The critical thinking ability of students who have low self efficacy is higher using the Student Teams Achievement Division learning model than using Teams Games Tournament learning model.
\end{abstract}

Keywords: Co-operative learning model, Self efficacy, Critical thinking ability, Social Science.

\section{INTRODUCTION}

The Effect Of Cooperative Learning Models And Self Efficacy To Critical Thinking Ability On Social Studies

Education is a very basic aspect of life for the development of a country. The importance of education, both formal and non-formal, is fully realized by the government. Education function to develop the ability and form the character and civilization of dignified nation in order to educate the nation's life, aims to develop the potential of learners to become human beings who believe and piety to God Almighty, noble, healthy, knowledgeable, capable, creative, independent, and become a democratic and responsible citizen.

Every human being has the potential to think. Through proper coaching, education, learning, and good observation, human thinking skills will also be able to thrive. One think that demands high-order thinking is critical thinking, because in critical thinking students are required to think reasonably and reflectively by using their reasoning and making decisions about what to do. So critical thinking is different from ordinary thinking.

Critical thinking skills, students will be able to analyze the idea or ideas towards more specific, classify and distinguish sharply, select, identify, assess and develop towards a more perfect. In addition students are also able to develop themselves in making decisions and solve problems. Someone will be able to think critically can ask appropriate questions, gather information needed, able to creatively and efficiently disseminate information to come to conclusions and decisions trustworthy and accountable.

Critical thinking skills include part of higher order thinking skills or HOTS. HOTS will make the students learn and understand the concepts of the lessons better and deeper. In addition, the students can distinguish HOTS or ideas in a clear, well argued, were able to solve the problem, is able to construct an explanation, able to make hypotheses and understand complex things become clearer.

As for Thyer (2013) states that there are six points of thought in critical thinking that is observe, evaluate, question, contextualize, reflection. The explanations are (1) the observe, which determines the theme to be observed, collects information from various sources, ensures that information is true at the moment; (2) analyze, that is, to certify the similarities or contradictions and decide to choose the topic of the problem based on information; (3) evaluate, that is to distinguish the value of information, differentiate information with pendpat, prioritize important information, and distinguish opinions with facts; (4) question, that is to consider alternative possibilities and develop new hypotheses; (5) contextualize, ie contextually related to 
consideration: historical, ethnic, political, cultural, environmental, and specific circumstances; (6) reflection, ie questions and conclusions test and reflect on the results.

Critical thinking ability can be defined as the ability to think clearly and rationally, where with the ability to think critically students can understand the problem better and can find the best answer to the problems encountered. Critical thinking ability of students, because the ability to think is a very important ability for life. The ability of a person to be successful in his life, among others determined by his ability to think, especially in an attempt to solve the problems of life he faced. The ability to think critically will influence the success of life because of what will be done and what will become the individual output.

According Lau (2011) about critical thinking, point of that:

Critical thinking is thinking clearly and rationally. It involves thinking precisely and systematically, and following the rules of logic and scientific reasoning, among other things. The quotation means that critical thinking is thinking clearly and rationally, encompassing precise and systematic thinking, following logical rules and scientific considerations. (p. 1).

The above opinion is supported by Cortrell's (2005) opinion is:

Critical thinking is a cognitive activity, associated with using the mind. Learning to think in critically analytical and evaluative means means through mental processes such as attention, categorization, selection, and judgment. The opinion explains that critical thinking is a cognitive activity, related to the use of the mind. Learning to think critically with critical analytical and evaluative way means using mental processes such as attention, categorization, selection, and assessment. (p. 1).

Critical thinking skills, students will be able to analyze the idea or ideas towards more specific, classify and

distinguish sharply, select, identify, assess and develop towards a more perfect. In addition students are also able to develop themselves in making decisions and solve problems. A person able to think critically will be able to ask the questions properly, collect the necessary information, be able to creatively and efficiently sort through the information to arrive at conclusions and decisions that can be trusted and accountable.

Glaser in Alec Fisher (2008:) argues that critical thinking is:

(1) an attitude of deep thinking about the problems and things that are different within the scope of a person's experience; (2) knowledge of methods of examination and logical reasoning; and (3) a kind of skill to apply those methods. Critical thinking demands a diligent effort to examine any assumptions or assumptive knowledge based on its supporting evidence and the subsequent conclusions it brings. (p. 3)

Nearly everyone who deals in the field of critical thinking has listed the thinking skills they perceive as the foundation for critical thinking. Glaser in Fisher (2008) listed several abilities:

1. Know the problem.

2. Find ways to deal with those problems.

3. Collect and compile necessary information.

4. Recognize unspecified assumptions and values.

5. Understand and use the correct language, clear, and distinctive.

6. Analyze data.

7. Assess facts and evaluate statements.

8. Recognize the logical relationship between problems.

9. Drawing conclusions and similarities are needed.

10. Examine the similarities and conclusions one takes.

11. Rearrange one's belief patterns based on a wider experience.

12. Make appropriate judgments about certain things and qualities in everyday life. (p. 7)

Based on the explanations stated above relate to the ability of critical thinking, the researchers conclude that the critical thinking skills is the ability to think groundless, reflective, open, clear, and is based on the fact by emphasizing decision-making.

In the context of education, self-efficacy should be owned by every student so that they are confident in their abilities so that no matter how difficult the material or repetition questions, they sure can solve it. In addition, self-efficacy encourages students to mature themselves as a form of preparing for a challenge.

Self-belief is the key to success. People who believe in themselves will establish both short-term and long-term life goals more directed. A person with high confidence will strive to achieve well-defined goals. They have confidence in their own success.

Self efficacy is one of the most important in improving students' learning activeness, where students must be confident in their ability to deal with problems in the learning process, because with the ability it has that students can easily solve the problems encountered. 
In his book, Bandura (2006) defines self efficacy is:

Self efficacy as perceived self-efficacy is defined as people ${ }^{e e}$ s beliefs about their capabilities to produce designated levels of performance that exercise influence over events that affect their lives. Self-efficacy beliefs determine how people feel, think, motivate themselves and behave. Such belief roduce these diverse effects through four major processes. They include cognitive, motivational, affective and selection processes. (p. 309)

The quotation can be interpreted that self efficacy as a belief that someone has on the ability to produce or demonstrate the level of ability in doing exercises that affect events that occur in life. Keyakikan self-efficacy determines how a person feels, thinks, behaves motivate himself in. Confidence produces differences that impact through four aspects of cognitive, motivational, affective, and other aspects.

Ormrod (2009, p.20) argue self-efficacy relates to an individual's judgment on his or her own ability to perform certain activities or behaviors and /or to achieve a particular goal.

Individuals with high self-efficacy prefer to allocate time and effort to tasks that can be completed. Individuals will be serious and try hard if you can be sure to complete the task. However, if the individual is not sure able to complete the task, then he will not mean it so that the results obtained will not be satisfactory.

High self-efficacy of a person, then the confidence in doing a certain response will be high. However, when a person's efficacy is low then self-confidence in resolving the response is also low. Such confidence will encourage someone's interest in something. High and low self efficacy can combine with a responsive and unresponsive environment.

Self-efficacy relates to an individual's judgment on his or her own ability to perform certain activities or behaviors and / or to achieve a particular goal. (Ormrod, 2009, p. 20)

Characteristic of individuals who have low self efficacy are individuals who feel helpless, quickly sad, apathetic, anxious, distancing themselves from difficult tasks, quickly give up when faced with obstacles, low aspirations and a weak commitment to goals to be achieved, in this difficult situation tends to think of their shortcomings, the severity of the task, and the consequences of its failure, and slow to restore the feeling of being able to after failure.

Based on the above description can be concluded that self efficacy or self efficacy is a belief in a person's ability to achieve a certain goal. Individuals who have high efficacy will strive to achieve what is desired without feeling anxious despite encountering obstacles or obstacles.

Learning model is one of the factors causing low ability of critical thinking of student. Based on the findings in the field, the students are less passionate or indifferent to the subjects given by the teacher, if the learning model is not in accordance with the characteristics of subject matter taught to students.

Cooperative learning models use small groups that work together and interdependence among group members and have sisal skills in completing their tasks with full responsibility. In another theory the same thing is expressed In cooperative learning every student has a role and must interact with each other responsibly.

Slavin in Tukiran (2012) suggest:

in cooperative learning methods, student work together in four member teams to master material initially presented by the teacher." From the description it can be argued that cooperative learning is a learning model in which the system of studying and working in small groups numbering 4-6 people collaboratively so as to excite students more enthusiastic in learning. (p. 55)

Cooperative learning models use small groups that work together and interdependence among group members and have sisal skills in completing their tasks with full responsibility. In another theory the same thing is expressed In cooperative learning every student has a role and must interact with each other responsibly.

Slavin (2009) argues that the Teams Games Tournament Model (TGT):

model is a model that uses a quiz or tournament at the end of the learning represented by each group. According to Slavin Teams Games Tournament model is one of the learning models that use academic tournaments. Quizzes, as well as an individual progress scoring system where students compete as representatives of their team with other members whose previous academic performance is on a par with them. Teams Games Tournament learning model is almost equal to the model of Student Teams Achievement Divisions (STAD) students. The difference is that STAD uses individual quizzes at the end of the lesson, while TGT uses academic games. (p. 143).

Teams Games Tournament learning steps (Tampubolon) consist of 8 steps, is:

1. Educators form groups of 4-5 people;

2. Each group deepens the material together prepared for the game;

3. The game consists of designed and numbered questions to test the knowledge gained by students from the presentation of the material in class and group work;

4. Learners choose numbered cards and try to answer questions that match the number. Learners who answer correctly will get a score

5. Scores of learners are collected for weekly tournaments (usually done at the end of the week or on each unit after the teacher has made a class presentation and the group has worked on the activity sheet); 
6. The first tournament, teachers divide learners into several tournament tables. Each high-achieving student is grouped on table 1 , the next three students on table 2, and so on;

7. Then the teacher announces the winning group. Each team will get a certificate or reward if the average score meets the criteria specified;

8. Team gets the nickname "Super Team" if the average score of 45 or more. Great team if the average score of 40-45, and Good Team if the average score of 30-40. (p. 96)

Based on the above theory, it can be synthesized that Team Games Tournament is a cooperative learning model that involves all student activities and puts students in 5- to 6-member study groups that have different abilities, genders, and tribes or races.

Student Teams Achievement Divisions are one of the methods or approaches in simple cooperative learning for teachers who are just beginning to use a cooperative approach in the classroom. STAD is a learning team consisting of four people of different levels of ability, gender and ethnic background. STAD can be used in a wide range of subjects ranging from math, language, arts and natural sciences.

Sumantri (2015) suggests that STAD is:

cooperative learning model is one type of cooperative that emphasizes the existence of activities and interactions among students to motivate each other and help each other in mastering the subject matter in order to achieve maximum achievement that has 5 stages of the delivery of materials, group work, individual tests, the calculation phase of individual development score, and confirmation. (p. 56)

According to Shoimin states that STAD type cooperative learning model consists of six step:

1) Teachers deliver learning materials to students according to basic competencies to be achieved. Teachers can use various options in conveying learning materials, eg, with guided discovery models or lecture methods. This step should not be done in one meeting, but more than one.

2) Teachers give test / quiz to each student individually so that will get initial value of student ability.

3) Teachers form several groups. Each group consists of 4-5 members, where group members have different academic skills (high, medium, and low). If possible, group members come from different cultures or tribes and pay attention to gender equality.

4) The teacher assigns the task to the group in relation to the material that has been given, discuss it together, help each other members and discuss the answer of the task given by the teacher. the ultimate goal is to ensure that each group member can master the concepts and materials. The task material for the group is prepared by the teacher so that the basic competencies expected can be achieved.

5) The teacher gives the test / quiz to each student individually.

6) The teacher facilitates the students in making summaries, directs, and affirms the learning materials they have learned.

7) Teachers reward groups based on the value of improving individual learning outcomes from the initial score to the next quiz score.

From the above opinion it can be synthesized that the Student Teams Achievement Division (STAD) learning model is a heterogeneous group learning model of 4-6 students from various races, gender, ability level and background that is expected to complete the task with full responsibility answer so as to improve student learning outcomes.

Based on the study of theory relevant to the above research variables, it can be concluded as hypothesis testing is as follows:

1. There is an influence between TGT learning model and STAD learning model on critical thinking ability in social studies subjects.

2. There is an interaction between the learning model and self-efficacy of critical thinking skills.

3. In self-efficacy high, students' critical thinking skills in the subjects of IPS given the model of learning TGT higher than the group given STAD learning model.

4. In low self efficacy, students' critical thinking ability in IPS subjects who are given STAD learning model is higher than those grouped with TGT learning model.

\section{METHOD}

The research method used in this research is experimental method. The experimental method was used to examine the presence or absence of influence by giving treatment to the experimental group and the results compared with the control class.In this study involves two independent variables that are Teams Games Tournament learning model and Student Teams Achievement Division learning model and one independent variable that is self efficacy, and involves one dependent variable that is critical thinking ability. So this study will compare two different learning models that are TGT learning model and STAD learning model with self efficacy to see critical thinking ability. 
International Journal of Advances in Scientific Research and Engineering (ijasre), Vol 4 (7), July - 2018

The research design using experimental method with treatment by level $2 \times 2$. The target population in this study is all students of class IV in Tanah Sareal District Bogor City as many as 41 Primary School. Affordable population of this study is the fourth grade students SDN Kedung Badak 2 academic year 2017/2018 as many as 20 students per class.

\section{RESULT}

Based on calculations that have been done manually using two way ANAVA, obtained the analysis as in the following table:

Table 1. ANAVA Interaction Result Between Cooperative Learning Model and Student Self Efficacy on Critical Thinking Ability

\begin{tabular}{|l|l|l|l|l|l|}
\hline Sumber Variansi & db & JK & RJK & F $_{\text {hitung }}$ & $\begin{array}{l}\text { F } \\
\text { tabel }\end{array}$ \\
\hline Antar Kolom & 1 & 34.225 & 34.22 & 11.59 & 4.11 \\
\hline Antar Baris & 1 & 13.22 & 13.22 & 4.48 & 4.11 \\
\hline Interaksi & 1 & 119.03 & 119.03 & 40.31 & 4.11 \\
\hline Dalam & 36 & 106.30 & 2.95 & & \\
\hline Total Direduksi & 39 & 272.775 & & & \\
\hline
\end{tabular}

The results of data testing of four groups using Kolmogrov Liliefors test with significance level $\alpha=0.05$ can be presented as follows:

a. Comparison of Critical Thinking Ability Between the TGT Learning Model and the STAD Learning Model.

The result of Variant Analysis (ANAVA) in table 4.10, obtained Fcount $=11,59$ and at Ftable $(0,05)=4,11$, then H0 is rejected. Thus, there are differences in students' critical thinking skills using the TGT learning model (A1) with the STAD learning model (A2). The average score of the group of students using the TGT learning model (A1) is XA1 = 33.6 with the group of students using the STAD learning model (A2) is XA2 $=31,75$.

This, it can be concluded that the critical thinking ability of students who learn to use TGT learning model is higher than students who learn to use STAD learning model.

b. Effect of Interaction Between Cooperative Learning Model and Self Efficacy Against Students Critical Thinking Skills

Result of Analasis Variant (ANAVA) in table 4.9, obtained Fcount $=40,31$ and at Ftable $(0,05)=4,11$, then H0 refused. Then there is a significant interaction effect between cooperative learning model and self efficacy on students' critical thinking ability.

After knowing the interaction between cooperative learning model and self efficacy of student hence required further test. The advanced test used is the Tukey Test. With Tukey Test it can be stated that there is a war of interaction between the provision of cooperative learning model and self efficacy. This can be seen from the picture below.

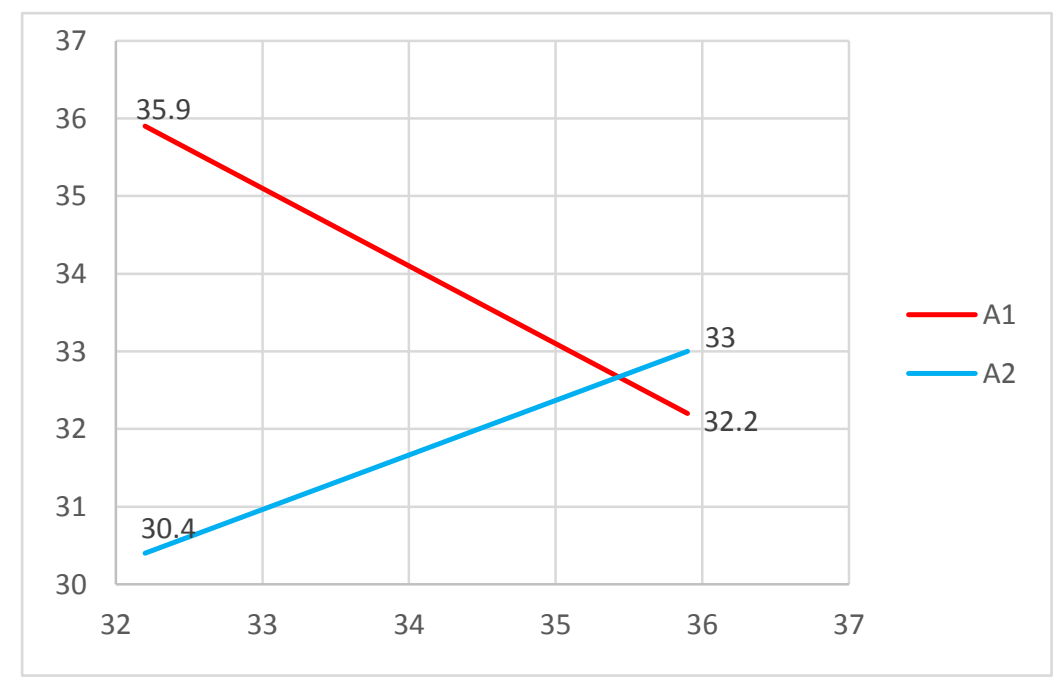

Figure 1. Graph of Interaction between Cooperative Learning Model and Self Efficacy on Critical Thinking Ability Information:

A1: TGT Learning Model

A2: STAD Learning Model

B1: High Self Efficacy

B2: Low Self Efficacy 
Roy Barli Sihombing et. al., The Effect Of Cooperative Learning Models And Self Efficacy ....

\section{c. Critical Thinking Ability of Students Who Have High Self-efficacy Using Leraning Model TGT \& STAD}

Testing using Tukey Test about the difference of critical thinking ability of students who have high self efficacy that was learned using TGT learning model with students who have high self efficacy using STAD learning model showed that Qcount $=9.75$ and Qtable $=2.042$, Then $\mathrm{H} 0$ rejected, it means there is significant difference in critical thinking ability in TGT learning model with STAD learning model in students who have high self efficacy or A1B1> A2B1 due to XA1B1 = 35,9 and $\mathrm{XA} 2 \mathrm{~B} 1=30,6$.

Thus, it can be concluded that the critical thinking skills of students who have high self-efficacy using TGT learning model is higher than students who have high self-efficacy using STAD learning model.

\section{d. The Critical Thinking Ability of Students Who Have Low Self-efficacy Using Learning Model TGT and STAD}

Testing using Tukey Test about the difference of critical thinking ability of students who have low self efficacy learned by using TGT learning model with students who have low self efficacy using STAD learning model shows that Qcount $=2.94$ and Qtable $=2.042$, Then H0 is rejected, it means there is a significant difference in critical thinking skills in the TGT learning model with STAD learning model in students who have high self efficacy or A1B1 <A2B1 due to XA1B2=31.3 and XA2B2 = 32.9.

Thus, it can be concluded that the critical thinking ability of students who have low self efficacy using TGT learning model is lower than students who have low self efficacy using STAD learning model.

\section{DISSCUSION}

The findings obtained in this hypothesis are the differences in critical thinking skills of students learning to use TGT learning model and STAD learning model. The students' critical thinking ability with TGT learning model is higher compared to students who learn to use STAD learning model.

This is because the TGT learning model is one of the learning models that classify the students heterogeneously, giving tasks done in groups, giving quizzes and ending with a tournament represented by each group to answer every question given by the teacher. The results of this tournament will make the group team as winners and awarded (reward).

While the STAD learning model is a model similar to the TGT learning model, there is only difference in the final stage where the STAD model asks questions to each student directly, so STAD model looks longer for the learning process.

The results of the above analysis is reinforced by the results of the calculation of the effectiveness of the use of TGT learning model and learning model of STAD in the whole obtained Fcount $=9.75$ on Ftable $(0.05)=4.11$, then H0 is rejected. Thus, there are differences in students' critical thinking skills using the TGT learning model (A1) with the STAD learning model (A2).

The second result of research is there is significant interaction effect between model of cooperative learning and self efficacy to critical thinking ability.

Teams Games Tournament (TGT) learning model and Student Teams Achievement Division (STAD) learning model emphasizes group work and shared responsibility in achieving goals and interaction between group members. With the proper application of TGT and STAD models can improve the learning motivation and self-efficacy of students in the classroom.

Self efficacy in general is a belief in a person's ability to achieve a certain goal without feeling anxious despite encountering obstacles or obstacles. Therefore, self efficacy can be seen from the way a person acts and is confident in a decision taken without fear of obstacles or obstacles that will be passed. Therefore, self efficacy gives a better influence in improving students' critical thinking skills.

The result of Variant Analysis (ANAVA) shows Fcount $=40,31$ at Ftable $(0,05)=4,11$, then H0 is rejected. Thus, there is a very significant interaction effect between the ICT media and the ability to think critically on the students' science literacy skills.

The result of the third study is the group of students who have high self-efficacy learning using TGT and STAD learning model.

Based on the characteristics possessed by students who have high self-efficacy, where students can go through obstacles and can solve a particular problem or obstacle. High self-efficacy when applied to the learning model will be more suitable to use Teams Games Tournament (TGT) learning model. Learning Model Teams Games Tournament is a model that provides an opportunity for students who already understand the learning materials to discuss and can guide friends and end with a group tournament between groups that will produce scores for each group. The group that has the greatest score, then the group is entitled to a reward / reward and deserves to be called the super group for having won the tournament in a lesson.

From these descriptions, it is suspected that critical thinking skills in Social Science subjects for students with high selfefficacy who learn to use Teams Games Tournament (TGT) learning model is higher than students learning by using Student Teams Achievement Divisions (STAD ). 
The results of the above analysis is reinforced by the results of the calculation of the overall data indicating that Qcount $=$ 9.75 and Qtabel $=2.042$, then $\mathrm{H} 0$ rejected, meaning there is a significant difference in self efficacy in the model of learning TGT in groups of students who have high self efficacy or A1B1> A2B1 XA1B1 $=35.9$ and XA2B1 $=30.6$

The fourth result showed that in the group of students who had low self efficacy in the study group using the TGT and STAD learning model.

In students who have low self-efficacy basically in improving the ability to think critically will be different from those who have high self-efficacy level. It is caused by self-induced factor causing the lack of self efficacy to do the learning process, so it will give negative impact to the learning process especially on students' self efficacy in social studies (IPS).

In the implementation of learning models Student Teams Achievement Divisions (STAD) and Teams Games Tournament (TGT) is a simple learning model. Students are placed in a heterogeneous study group. Teachers present lessons and students work in groups to ensure that all members master the lesson. Finally, all students carry out evaluation activities in the form of quiz for STAD model and tournament for TGT model.

In this case, it is suspected that critical thinking skills in Social Science subjects for students with low self-efficacy who learn to use the Student Teams Achievement Divisions (STAD) learning model is higher than students learning by using Teams Games Tournament (TGT).

The result of the above analysis is reinforced by the calculation result which shows that Qcount $=2,94$ and Qtable $=2.042$, then $\mathrm{H} 0$ is rejected, meaning there is significant difference of critical thinking ability with TGT learning model and STAD learning model in student group having low self efficacy or A1B2 $\angle \mathrm{A} 2 \mathrm{~B} 2$ due to $\mathrm{XA} 1 \mathrm{~B} 2=31.3$ and $\mathrm{XA} 2 \mathrm{~B} 2=32.9$.

\section{CONCLUSIONS}

In the context of this research, the implications of the research findings are related to efforts to improve the critical thinking skills of elementary school students by considering the model of learning and self-efficacy of the students.

1. Improving Student's Critical Thinking Ability through TGT Learning Model

Empirical evidence through this study indicates that students' critical thinking skills score in students learning to use TGT learning model is higher than students learning to use STAD learning model. Thus the effort to improve students' critical thinking ability by considering self efficacy can be done by using TGT learning model as learning process of IPS in elementary school.

2. Improvement of Critical Thinking Ability of Students Who Have High Self-efficacy Through TGT Learning Model.

Empirical evidence through this study indicates that for students who have high self-efficacy, critical thinking skills of students who learn to use TGT learning model on IPS subjects proved higher than students who learn to use STAD learning model. Thus efforts to improve students' critical thinking skills with self efficacy can be pursued by the TGT learning model as an IPS learning process in primary school.

3. Improvement of Critical Thinking Skills SIswa Who Have Low Self Efficacy Through STAD Learning Model

Empirical evidence through this study indicates that for elementary school students who have low self-efficacy, critical thinking skills of students who learn to use STAD learning model in IPS learning in primary school proved higher than students who learn to use TGT learning model. Thus the effort to improve students' critical thinking ability with low self efficacy of students, can be pursued by STAD learning model as learning process of IPS in elementary school.

Based on result of analysis and discussion which have been described in this research hence can get the following findings:

First, the critical thinking skills of elementary school students who are learning to use Teams Games Tournament (TGT) learning models are higher than students learning to use the Student Teams Achievement Divisions (STAD) learning model. Second, there is an interaction effect between the use of learning model and self efficacy on critical students' critical thinking skills. Third, students who have high self-efficacy using TGT learning model are higher than students using STAD learning model. Fourth, students who have low self-efficacy using STAD learning models are higher than students learning to use the TGT model.

Based on the above findings, it can be concluded that the influence of learning models on students' critical thinking skills. Students who learn to use TGT learning models get higher critical thinking skills than students learning to use STAD learning models. The existence of interaction between the use of learning model and self efficacy to the high low critical thinking ability. Students who have high self-efficacy will have a better effect on students' critical thinking skills when students learn to use the TGT learning model. Conversely pad students who have low self efficacy will have a better effect on students' critical thinking skills when students learn to use STAD learning model.

\section{REFERENCES}

1. Alec Fisher. (2008) "Sebuah Pengantar Berpikir Kritis. Jakarta: Erlangga.

2. Bandura, Albert. (28 Agustus 2017) “Guide For Constructing Self-Efficacy Scales Chapter 14”. Retrieved from

3. Lau, Joe Y.F. (2011) “An Intorudction to Critical Thinking and Creativity”. Canada: Wiley. 
4. Ormrod, J.E. (2009) "Psokologi Pendidikan” (Penerjemah: Amitya Kumara). Jakarta: Erlangga.

5. Slavin, Robert E. (2009) “Cooperative Learning Teori Riset dan Praktik” (Alih Bahasa: Nurita Yusron). Bandung: Nusa Media.

6. Stella Corttrell. (2005) “Critical Thinking Skills”. (New York: Palgrave Macmillan, 2005).

7. Taniredja, Tukiran dkk. (2012) "Model-Model Pembelajaran Inovatif” Bandung: Alfabeta.

8. Mohamad Syarif Sumantri, Strategi Pembejaran (Jakarta: Raja Grafindo Persada, 2015) h. 56

9. Saur Tampubolon, Penelitian Tindakan Kelas Untuk Pengembangan Profesi Pendidik dan Keilmuan (Jakarta: Erlangga, 2014) h. 96

10. Thyer, http://www.deakin.edu.au/data/assets/pdf_file/0012/51222/critical-thinking.pdf 